\title{
Explaining Executive Compensation: Managerial Power versus the Perceived Cost of Stock Options
}

\author{
Kevin J. Murphy†
}

The 1990s were a great time to be a top executive in a large U.S. company. Figure 1 shows the median total compensation of chief executive officers in S\&P 500 Industrials (that is, the S\&P 500 companies excluding utilities and finance firms) from 1992 through 2000. The bar height depicts median total compensation in CPI-adjusted 2001constant dollars, including salaries, realized bonuses, stock options, and other pay.' Over this period, median total compensation nearly tripled from $\$ 2.3$ million in 1992 to over $\$ 6.5$ million in 2000 . Figure 1 also depicts how the composition of CEO pay has evolved over time. The figure shows that the increase in CEO pay in S\&P 500 Industrials during the 1990s primarily reflects a dramatic growth in stock options (valued on date of grant), which swelled from 27 percent to 51 percent of total compensation, representing a five-fold increase in dollar terms.

Table 1 shows that the option-driven escalation in CEO pay levels is not limited to S\&P 500 Industrials. Panel A shows that median pay in S\&P 500 Financial Services companies increased 300 percent, from $\$ 2.6$ million to almost $\$ 11$ million from 1992 to 2000 , while pay in smaller firms (defined as companies in the S\&P MidCap 400 and SmallCap 600) more than doubled, from $\$ 823,000$ to $\$ 1.8$ million. Median pay in so-called "New Economy" firms increased 130 percent, from $\$ 1.4$ million to $\$ 3.2$ million. ${ }^{3}$ Panel $B$ shows that the large pay in-

$\dagger$ Professor, Marshall School of Business and School of Law, University of Southern California.

1 Data from Standard \& Poor's ("S\&P's") ExecuComp database, available online at $<$ http://www.compustat.com> (visited Apr 27, 2002). Stock options are valued using ExecuComp's modified Black-Scholes methodology (which uses an expected life equal to 70 percent of the actual term, and truncates unusually high or low volatilities and dividend yields). Other compensation includes restricted stock grants, payouts from long-term incentive plans, perquisites, and benefits.

2 Pay component percentages are derived from S\&P's ExecuComp data by computing the percentages for each $\mathrm{CEO}$, and averaging across CEOs.

3 I define New Economy firms as companies with primary Standard Industrial Classification ("SIC") designations of 3570 (Computer and Office Equipment), 3571 (Electronic Computers), 3572 (Computer Storage Devices), 3576 (Computer Communication Equipment), 3577 (Computer Peripheral Equipment), 3661 (Telephone and Telegraph Apparatus), 3674 (Semiconductor and Related Devices), 5045 (Computers and Software Wholesalers), 5961 (Electronic 
creases in these three categories of companies is driven primarily by increasing stock option grants.

\section{FIGURE 1 \\ CEO PAY IN S\&P 500 INDUSTRIALS, 1992-2000}

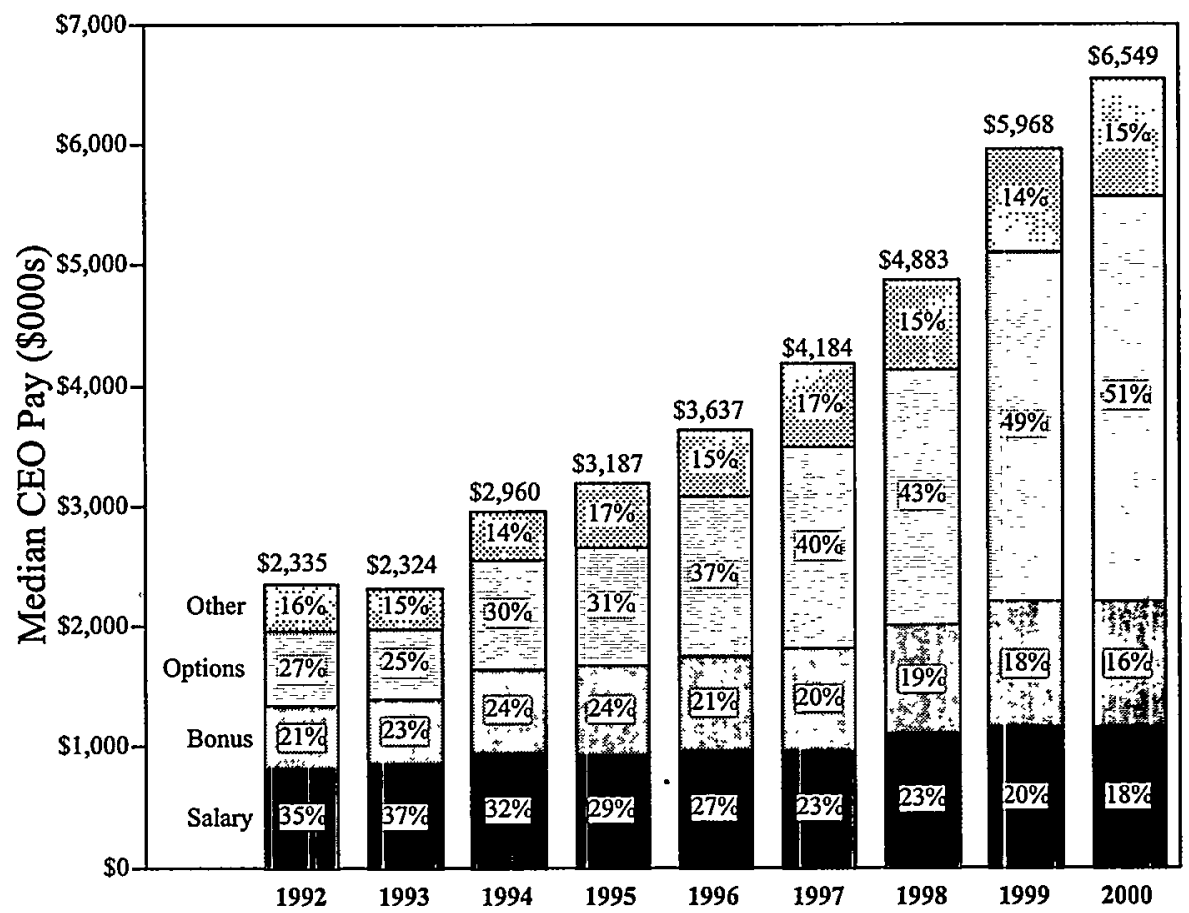

Note: Median pay levels (in 2001-constant dollars) based on S\&P's ExecuComp data for S\&P 500 CEOs (financial firms and utilities excluded). Total compensation (indicated by bar height) defined as the sum of salaries, bonuses, benefits, stock options (valued on date of grant using the Black-Scholes formula), stock grants, and other compensation.

Lucian Bebchuk, Jesse Fried, and David Walker ("BFW") argue that "much of what is observed in the world of executive compensation" can be explained by managerial opportunism and influence over captive boards of directors. ${ }^{4}$ Under their "managerial power" hypothesis, executive pay practices reflect the actions of powerful executives who can influence the terms of their own pay packages, and do so in a way that "camouflages" pay to mitigate external scrutiny and criticism. While acknowledging that the "optimal contracting" and "managerial

Mail-Order Houses), 7370 (Computer Programming and Data Processing), 7371 (Computer Programming Service), 7372 (Prepackaged Software), and 7373 (Computer Integrated Systems Design).

4 Lucian Bebchuk, Jesse Fried, and David Walker, Managerial Power and Executive Compensation, 69 U Chi L Rev 751, 785 (2002). 
power" explanations are not mutually exclusive and that both may play a role, BFW conclude that the managerial power view can better explain patterns and practices of executive compensation. In particular, BFW argue that managerial power can explain several "puzzling" features of option plans, including why exercise prices are set at grantdate market prices and are not indexed to general market movements (but are often reset following market declines), why options often contain so-called "reload" provisions, and why firms allow executives to exercise early and diversify (or otherwise hedge the risk of their option and stock holdings). In addition, BFW claim that managerial power explains why U.S. executives earn higher pay than their international counterparts, and why CEO pay is higher for CEOs with more power.

TABLE 1

Median Compensation and Options as Percent of Pay for

CEOS IN FINANCIAL FIRMS, SMALL FIRMS, AND NEW ECONOMY FIRMS, 1992-2000

\begin{tabular}{|c|c|c|c|c|c|c|}
\hline \multirow[b]{2}{*}{$\begin{array}{l}\text { Fiscal } \\
\text { Year }\end{array}$} & \multicolumn{3}{|c|}{$\begin{array}{l}\text { PANELA. } \\
\text { Median Total Compensation ( } \$ 000 \mathrm{~s})\end{array}$} & \multicolumn{3}{|c|}{$\begin{array}{l}\text { PANEL B. } \\
\text { Average Option Grant as Percent of } \\
\text { Total CEO Pay }\end{array}$} \\
\hline & $\begin{array}{l}\text { S\&P } 500 \\
\text { Financial }\end{array}$ & $\begin{array}{l}\text { Smaller } \\
\text { Firms }\end{array}$ & $\begin{array}{l}\text { New } \\
\text { Economy }\end{array}$ & $\begin{array}{l}\text { S\&P } 500 \\
\text { Financial }\end{array}$ & $\begin{array}{l}\text { Smaller } \\
\text { Firms }\end{array}$ & $\begin{array}{l}\text { New } \\
\text { Economy }\end{array}$ \\
\hline 1992 & $\$ 2,621$ & $\$ 823$ & $\$ 1,418$ & $19.2 \%$ & $18.5 \%$ & $35.0 \%$ \\
\hline 1993 & $\$ 2,832$ & $\$ 929$ & $\$ 1,298$ & $20.6 \%$ & $19.4 \%$ & $36.4 \%$ \\
\hline 1994 & $\$ 3,150$ & $\$ 1,074$ & $\$ 1,609$ & $30.1 \%$ & $22.7 \%$ & $37.5 \%$ \\
\hline 1995 & $\$ 3,126$ & $\$ 1,063$ & $\$ 1,371$ & $22.0 \%$ & $20.3 \%$ & $36.8 \%$ \\
\hline 1996 & $\$ 4,702$ & $\$ 1,240$ & $\$ 1,452$ & $30.7 \%$ & $26.0 \%$ & $42.1 \%$ \\
\hline 1997 & $\$ 5,483$ & $\$ 1,473$ & $\$ 2,163$ & $35.9 \%$ & $28.6 \%$ & $49.4 \%$ \\
\hline 1998 & $\$ 6,341$ & $\$ 1,583$ & $\$ 1,958$ & $42.8 \%$ & $32.6 \%$ & $48.7 \%$ \\
\hline 1999 & $\$ 8,978$ & $\$ 1,685$ & $\$ 2,513$ & $49.3 \%$ & $35.7 \%$ & $55.5 \%$ \\
\hline 2000 & $\$ 10,726$ & $\$ 1,767$ & $\$ 3,241$ & $49.3 \%$ & $35.7 \%$ & $54.3 \%$ \\
\hline
\end{tabular}

Note: Data from S\&P's ExecuComp database. S\&P 500 exclude financial services (SIC codes 6000-6999) and utilities (4900-4999). Smaller firms are those in S\&P's MidCap 400 and SmallCap 600. New economy firms defined as companies with primary SIC codes $3570,3571,3572,3576$, $3577,3661,3674,5045,5961,7370,7371,7372$, and 7373. Total pay (in 2001-constant dollars) includes salaries, bonuses, stock options, restricted stock, payouts from long-term plans, and benefits. Stock options are valued at the grant-date using ExecuComp's modified Black-Scholes methodology. 
The BFW analysis is comprehensive and provocative, and their evidence that pay practices reflect more than optimal contracting concerns is compelling. Equally compelling is their evidence that most pay decisions are not made by truly independent boards in legitimate arm's length transactions. Ultimately, though, their managerial power view is both problematic as a theoretical matter, and too simplistic to explain executive pay practices. Moreover, their hypothesis is largely inconsistent with the most important development in executive compensation practices: the recent escalation in option-based compensation for both top-level and lower-level executives. Overall, their prescription to focus on rent extraction in examining "the regulation and practice of corporate governance" is potentially misguided and diverts attention from more important issues regarding executive compensation.

I begin in Part I of this Commentary by examining the managerial power hypothesis, which asserts that incumbent executives exercise power and influence over captive directors in order to extract rents through their compensation arrangements. I show that the escalation in executive pay during the 1990 s coincided with increasingly independent corporate boards; this evidence is inconsistent with the managerial power hypothesis. In addition, I show that CEOs hired from the outside with no ties to the existing board enjoy especially attractive pay packages; this evidence is also directly inconsistent with the view that CEOs use their relationships with their boards to extract rents. I also distinguish between rent extraction (which requires captive boards) and CEO bargaining power (which can generate higher pay even in arm's length transactions), and offer reasons why CEO bargaining power may have increased in recent years. This distinction is important: the ability to extract rents or bargain might both be described as "managerial power" and suggest very different efficiency implications and policy prescriptions.

Part II critiques the "outrage costs" introduced by BFW in conjunction with their managerial power hypothesis. BFW argue that these costs explain why rent-extracting executives seek to increase pay levels through option grants rather than through increases in cash compensation (because doing so reduces public outrage), and why firms use compensation consultants and adopt uniform compensation practices (because following "norms" minimizes outrage). I establish that these costs are critical in developing their managerial power hypothesis, since otherwise managerial power would affect the level but not necessarily the structure of executive pay. I present historical evidence on "outrage" which suggests that the trends in pay illustrated in Figure 1 are starkly at odds with the BFW hypothesis. Finally, I argue that the outrage costs as developed by BFW are sufficiently vague to 
be irrefutable-the authors can argue that virtually any unobserved practice is avoided because it would cause outrage.

Part III offers an alternative hypothesis that I believe explains pay patterns and practices better than both the optimal contracting and managerial power views. The hypothesis is based on two assumptions: (1) risk-averse and undiversified executives (and employees) understand that stock option compensation is highly risky, and discount the value of options appropriately; and (2) because of accounting and cash-flow considerations, companies routinely (but inappropriately) treat options as relatively inexpensive ways to convey compensation. I offer evidence supporting these assumptions, including the increasing prevalence of "broad-based" option programs difficult to justify from both an optimal contracting and managerial power perspective. I show how this alternative hypothesis can explain why exercise prices for options are set at or below current market prices and are not indexed for market movements, why options were repriced following market downturns and why this practice has largely disappeared, why options often contain reload provisions, and why firms allow executives to exercise early and diversify.

In the Conclusion, I contrast the policy implications suggested by the managerial power and "perceived-cost" views of executive compensation. Prescriptions to mitigate managerial power problems focus on corporate governance solutions such as increased board independence. In contrast, prescriptions to mitigate perceived-cost problems focus on director education and changes in accounting and tax rules.

\section{THE MANAgerial POWER VIEW}

Underlying the BFW managerial power hypothesis are two indisputable facts: (1) CEOs (like the rest of us) prefer more rather than less compensation, and (2) CEOs and other top managers are able to influence both the level and structure of their pay. In an earlier work, I observed that the CEO's influence over pay is typically indirect, and reflects that judgment calls by well-intentioned boards tend systematically to favor the CEO. For example, faced with a range of market data on competitive pay levels, committees tend to err on the high side. ${ }^{6}$ Or, faced with a choice between a sensible compensation plan and a slightly inferior plan favored by the CEO, the committee will defer to management. ' However, the existence of these opportunities

5 Kevin J. Murphy, Executive Compensation, in Orley Ashenfelter and David Card, eds, 3B The Handbook of Labor Economics 2485, 2517-18 (Elsevier 1999) (dismissing the claim that "entrenched compensation committees" rubber stamp lucrative pay programs for CEOs).

6 Id at 2518.

7 Id. 
for rent extraction does not necessarily imply that executives are effective in exploiting these self-enrichment opportunities, or that such behavior (to the extent it exists) has a first-order effect in explaining patterns and practices of CEO pay.

BFW argue that even nominally independent boards are not truly independent because the CEO controls the nomination process, maintains social relations with board members, and expects board support. They argue that "boards have become more effective monitors of the CEO performance during the 1990s," citing evidence that independent directors increasingly constitute a majority of the board and its key committees (including nominating and compensation). ${ }^{8}$ This trend toward more independent boards, coupled with the simultaneous escalation in CEO pay illustrated in Figure 1, seems directly inconsistent with the hypothesis that CEO pay patterns and practices are driven by managerial power considerations.

The managerial power view focuses on incumbent executives exercising power and influence over outside directors who are "connected to the executives by bonds of interest, collegiality, or affinity." Therefore, one way to test the managerial power hypothesis is to compare the compensation of CEOs hired from the outside (without established connections to the board) to CEOs hired from the inside (who presumably have such connections). Table 2 presents ordinary least-squares regressions of the logarithm of cash pay and total pay for the sample of newly hired CEOs in the ExecuComp database. Independent variables include a dummy variable if the new CEO was hired from the outside (rather than from within the company), the logarithm of sales to control for company size, and dummy variables for S\&P 500 firms, financial services firms, utilities, new economy firms, and fiscal years. 
TABLE 2

ORDINARY LEAST SQUARES REGRESSIONS OF THE LOGARITHM OF Cash Pay and Total Pay for NeWLy HiRed CEOS, 1992-2000

\begin{tabular}{|c|c|c|c|c|}
\hline \multirow[b]{2}{*}{$\begin{array}{l}\text { Independent } \\
\text { Variable }\end{array}$} & \multicolumn{2}{|c|}{$\begin{array}{l}\text { PANELA } \\
\text { New CEOs in First Partial Year }\end{array}$} & \multicolumn{2}{|c|}{$\begin{array}{l}\text { PANEL B } \\
\text { New CEOs in First Full Year }\end{array}$} \\
\hline & Ln(Cash Pay) & Ln(Total Pay) & $\operatorname{Ln}($ Cash Pay) & Ln(Total Pay) \\
\hline & (1) & (2) & (3) & (4) \\
\hline Intercept & 4.823 & 5.621 & .4 .946 & 5.488 \\
\hline $\begin{array}{l}\text { (Dummy) } \\
\text { Outside Hire }\end{array}$ & $-.2435(-3.1)$ & $.6759(8.1)$ & $.0364(0.5)$ & $.1244(1.2)$ \\
\hline Ln(Sales) & $.2784(12.5)$ & $.2794(12.0)$ & $.2522(12.7)$ & $.2952(10.3)$ \\
\hline $\begin{array}{l}\text { (Dummy) } \\
\text { Finance }\end{array}$ & $.2836(2.3)$ & $.1719(1.3)$ & $.2715(2.6)$ & $.2463(1.6)$ \\
\hline & $-.2890(-2.2)$ & $-.7321(-5.4)$ & $-.3338(-3.1)$ & $-.4384(-2.9)$ \\
\hline $\begin{array}{l}\text { (Dummy) } \\
\text { S\&P } 500\end{array}$ & $.1576(1.9)$ & $.5208(5.9)$ & $.2031(2.8)$ & $.3712(3.5)$ \\
\hline $\begin{array}{l}\text { (Dummy) } \\
\text { New Economy }\end{array}$ & $-.1668(-1.8)$ & $.2873(3.0)$ & $.0939(1.0)$ & $.3561(2.6)$ \\
\hline Year Dummies & Yes & Yes & Yes & Yes \\
\hline $\mathbf{R}^{2}$ & $34 \%$ & $43 \%$ & $42 \%$ & $37 \%$ \\
\hline Sample Size & 645 & 643 & 461 & 460 \\
\hline
\end{tabular}

Note: t-statistics in parentheses. Sample is based on all new CEOs in the S\&P 500, the S\&P MidCap 400, and the S\&P SmallCap 600. Cash pay includes salaries and bonuses. Total pay includes salaries, bonuses, stock options, restricted stock, payouts from long-term plans, and benefits. Stock options are valued at the grant-date using ExecuComp's modified Black-Scholes methodology. Outside hires are defined as individuals who have been employed by the company for less than one year before their appointment as CEO.

Panel A of Table 2 analyzes compensation for newly hired CEOs in their first partial year as CEO. The coefficient on "outside hires" in column (1) is negative and significant, indicating that CEOs hired from the outside earn about 22 percent less cash compensation than CEOs hired from inside the firm. ${ }^{10}$ This negative coefficient might reflect that outside hires are unable to extract rents and earn lower pay levels, but more plausibly reflects partial-year compensation: although inside hires only receive CEO pay for a fraction of the year, they receive pay in other positions for the earlier'portion of the year. However, column (2) shows that outside hires earn 96 percent more total compensation than do inside hires. Under the managerial power hypothesis, new hires from outside the company are expected to earn lower total pay levels (because they cannot yet extract rents from the board) but relatively higher cash compensation (since there is no need 
to camouflage payments through stock-based pay). The results that outside hires earn lower cash compensation but higher total compensation (primarily reflecting stock options, restricted stock grants, and sign-on bonuses) are inconsistent with the managerial power hypothesis.

Fee and Hadlock show that incoming executives receive initial option and stock grants that (more than) offset the value of unvested options and stock cancelled when they left their former employer." These findings are consistent with the results in Table 2 but are inconsistent with the BFW managerial power hypothesis, since if payments reflect rents created by captive boards, these rents should not be transferable to other firms. In any case, Panel B of Table 2 analyzes compensation for new CEOs in their first full fiscal year as CEO. These data are not contaminated by partial-year compensation or one-time payments made to outside hires for benefits lost at former employers. The results in columns (3) and (4) show that, by the first full fiscal year, cash and total compensation is insignificantly higher for CEOs hired from the outside than for CEOs hired from the inside. Since the outside hires have weaker ties to the current board, these results again are inconsistent with the managerial power hypothesis.

In fact, the mere existence of outside hires is largely inconsistent with the managerial power view, because systematic rents above competitive pay levels will make executives less likely to leave voluntarily, and make attracting executives from other firms more expensive. But, as documented in my earlier work, companies in the 1990s (when rent extraction through the exercise of managerial power was supposedly high) were much more likely to hire CEOs from outside the company than in the 1980s or 1970s. And, as documented by Fee and Hadlock, executives changing companies during the 1990s received large pay increases, indicating that alleged "rents" were transferable (which suggests they are not rents at all).

If not rent extraction, then why have pay levels increased so dramatically over the past decade? One plausible alternative explanation is that CEO bargaining positions have increased over this time period, perhaps because CEO marginal productivities have increased, ${ }^{14}$ or be-

11 C. Edward Fee and Charles J. Hadlock, Raids, Rewards, and Reputations in the Market for CEO Talent at 31, working paper (2001), available online at <http://www.afajoforg/ Pdf/meeting/2002/fee_paper.pdf $>$ (visited Apr 19, 2002) (reporting that CEOs receive higher stock options from their new employers than they did with their previous employer).

12 Murphy, Executive Compensation at 2545-50 (cited in note 5) (showing trends in outside CEO hires since 1970).

13 See Fee and Hadlock, Raids, Rewards, and Reputations at 32 (cited in note 11) (finding that "the overwhelming majority of job movements ... [resulted] in substantial raises).

14 See Charles P. Himmelberg and R. Glenn Hubbard, Incentive Pay and the Market for CEOs: An Analysis of Pay-for-Performance Sensitivity at 3-4, working paper (2000), available 
cause general "managerial capital" has become important relative to firm-specific capital. Changes in bargaining power are consistent with both efficiency and with arm's length negotiations (which, after all, do not require a perfectly competitive market for managerial talent), and are importantly distinct from rent extraction (even though both predict higher-paid top executives).

\section{OUTRAGE COSTS}

Under the managerial power hypothesis proposed by BFW, extractable rents are ultimately limited by "outrage costs." BFW use outrage costs to explain why option plans (exercise prices, vesting provisions, etc.) across firms are generally uniform (because following "norms" reduces outrage) and why companies use compensation consultants. In earlier drafts of their Article, they also used outrage costs to explain the recent escalation in stock options (because cash would generate more outrage).

Outrage costs are critical to the $\mathrm{BFW}$ analysis, since without these costs there is no reason to expect a priori that rent extraction would affect the structure rather than just the level of executive pay. Suppose, for example, that managerial power resulted in the CEO holding too many stock options from an optimal contracting perspective. Then, we would expect to observe voluntary and Paretoimproving transactions where the executive exchanges options for increased cash compensation, increasing both executive welfare and company profits. (Formally, ignoring what economists call wealth effects, the derived optimal contract is the same if one maximizes firm profits holding constant executive utility, or maximizes executive utility holding constant firm profits.)

I am sympathetic to the view that external perceptions can influence executive pay. ${ }^{15}$ And there exists some anecdotal evidence supporting the importance of outrage costs. ${ }^{16}$ However, there is little evidence that public outrage has played an important role in influencing the patterns and practices of CEO pay depicted in Figure 1. In fact,

online at $<\mathrm{http}: /$ www.gsb.columbia.edu/faculty/ghubbard/Papers/ceo10.pdf $>$ (visited Apr 19, 2002) (arguing that increased CEO compensation may be related to increased marginal productivity, market demand for CEOs, and the supply elasticity of CEOs with similar skills).

15 As noted by BFW, the outrage constraint is conceptually similar to the "political constraint" introduced by Michael C. Jensen and Kevin J. Murphy, Performance Pay and TopManagement Incentives, 98 J Polit Econ 225, 262 (1990) (suggesting that "political forces" limit large payofis for exceptional performance).

16 For example, in 1991, General Dynamics was intensely criticized for its "Gain Sharing" plan that provided cash payouts for increases in the company's stock price. When the company replaced the cash plan with a traditional option plan (that provided roughly the same payouts) the criticism abated. See Jay Dial and Kevin J. Murphy, Incentives, Downsizing, and Value Creation at General Dynamics, 37 J Fin Econ 261, 261-64 (1995). 
the surprising lack of outrage over the recent escalation in CEO pay has been one of the more striking developments of the last decade."

Public perceptions of CEO pay clearly surpassed the "outrage" level in 1991-92. ${ }^{18}$ Feature stories on CEO pay aired on the nightly news broadcasts of the three major networks. $\mathrm{CNN}, 60$ Minutes, and Nightline also devoted segments to CEO pay. ${ }^{20}$ The controversy heightened with the introduction of Graef Crystal's 1991 exposé on CEO pay, In Search of Excess. ${ }^{21}$ By the 1992 presidential elections, all leading candidates had position statements on escalating CEO pay. Legislation was introduced in both the House and the Senate to curb runaway executive compensation, the Securities and Exchange Commission passed sweeping new disclosure rules to make compensation more transparent, and the Financial Accounting Standards Board began an ultimately unsuccessful campaign to impose an accounting charge for executive options.

How did the 1991-1992 outrage episode affect executive compensation? Apparently, not much. From 1992 to 2000, median salaries for S\&P 500 CEOs increased by 17 percent after inflation while bonuses doubled. ${ }^{23}$ Moreover, the escalation in stock option compensation documented in Figure 1 and Table 1 was not "caused" by the outrage but rather continued a trend towards option compensation that began in the mid-1980 $\mathrm{s}^{24}$

In fact, the new SEC disclosure rules introduced in 1992 were focused primarily on providing better details on stock option compensation, thus making it harder for CEOs to camouflage or hide compensation in stock options. The fact that trends in option grants continued

17 See David Leonhardt, Why Is This Man Smiling?: Executive Pay Drops Off the Political Radar, NY Times D5 (Apr 16, 2000) (noting that although executive salaries soared during the 1990s, "outrage is minimal").

18 I discuss the causes and consequences of this public outrage more fully in Kevin J. Murphy, Politics, Economics, and Executive Compensation, $63 \mathrm{U}$ Cin L Rev 713, 713-17 (1995).

19 Id at 713.

20 Id.

21 Graef S. Crystal, In Search of Excess (Norton 1991).

22 Jeffrey H. Birnbaum, Campaign '92: From Quayle to Clinton, Politicians Are Pouncing on the Hot Issue of Top Executive's Hefty Salaries, Wall St J A14 (Jan 15, 1992). Bill Clinton promised to "end the practice of allowing companies to take unlimited tax deductions for excessive executive pay." Id. George Bush's running mate, Dan Quayle, warned that corporate boards should "curtail some of these exorbitant salaries paid to corporate executives that are unrelated to productivity." Id. Bob Kerrey called it "unacceptable' for corporate executives to make millions of dollars while their companies are posting losses." Id. Paul Tsongas argued that "excessive pay is hurting America's ability to compete in the international marketplace." Id. Pat Buchanan argued, "You can't have executives running around making $\$ 4$ million while their workers are being laid off." Id.

23 See Figure 1.

24 See Brian J. Hall and Jeffery B. Liebman, Are CEOs Really Paid Like Bureaucrats?, 113 Q J Econ 653, 653-91 (1998) (discussing the "Iarge increase in CEO holdings of stock and stock options that occurred between 1980 and 1994"). 
unabated following these disclosure rules suggests that the BFW "outrage constraint" was not binding.

The evidence from the 1990s suggests that public outrage has not driven executive pay practices. However, the primary problem with the BFW view of outrage costs is not the lack of empirical support but rather that, as developed, it is irrefutable. For example, BFW argue that companies grant "at the money" options, hire compensation consultants, and adhere to established norms because doing otherwise would cause outrage. Taken to its extreme, the authors could argue that virtually any unobserved practice is avoided because it would be considered outrageous. Before concluding that otherwise-preferred compensation arrangements are avoided because of outrage costs, it is necessary to provide evidence that (1) the arrangements would, in fact, cause outrage, and (2) that the outrage costs exceed the benefits of the otherwise-preferred compensation arrangements.

\section{THE PERCEIVED-COST VIEW}

Under the optimal contracting approach adopted by most financial economists, stock options are viewed as incentive compensation that provides a direct link between executive pay and company performance. This incentive rationale for stock options, however, holds at most for top-level executives who can take direct actions that affect company stock prices and does not hold for lower-level managers and employees. And yet, most options are granted to employees below the top executive level. ${ }^{25}$ Table 3 shows the average percentage of annual option grants awarded to executives and employees below the top five "proxy-named" executives. ${ }^{26}$ The table shows that nearly 80 percent of options granted in S\&P 500 Industrials, S\&P 500 Financials, and New Economy firms in 2000 were granted to executives and employees below the top five and also shows that grants below the top five (as a percent of all grants) have been generally increasing since 1992 in all sectors. These results indicate that the escalation in option-based compensation illustrated in Table 1 and Figure 1 is not limited to the CEO but rather reflects a proportional escalation for executives below the top tier.

25 See, for example, John E. Core and Wayne R. Guay, Stock Option Plans for NonExecutive Employees, $61 \mathrm{~J}$ Fin Econ 253, 265 (2001) (noting that 66.9 percent of options are held by non-executive employees).

26 Calculations are based on ExecuComp data and include only firms where at least one of the top five executives received options during the year. 
TABLE 3

Percentage of ANNuAl Option Grants Awarded to
Executives and EMPloyees below thiE TOP Five, 1992-2000

\begin{tabular}{llllll}
\hline $\begin{array}{lllll}\text { Fiscal } \\
\text { Year }\end{array}$ & & $\begin{array}{l}\text { S\&P 500 } \\
\text { Industrials }\end{array}$ & $\begin{array}{l}\text { S\&P 500 } \\
\text { Financial }\end{array}$ & $\begin{array}{l}\text { Smaller } \\
\text { Firms }\end{array}$ & $\begin{array}{l}\text { New } \\
\text { Economy }\end{array}$ \\
\cline { 1 - 3 } 1992 & & $77.6 \%$ & $75.2 \%$ & $63.9 \%$ & $78.0 \%$ \\
1993 & & $75.7 \%$ & $77.6 \%$ & $62.0 \%$ & $78.1 \%$ \\
1994 & & $74.2 \%$ & $71.8 \%$ & $62.2 \%$ & $76.1 \%$ \\
1995 & & $76.4 \%$ & $77.5 \%$ & $63.5 \%$ & $77.7 \%$ \\
1996 & & $76.1 \%$ & $72.6 \%$ & $62.9 \%$ & $76.8 \%$ \\
1997 & & $76.1 \%$ & $73.1 \%$ & $63.0 \%$ & $77.5 \%$ \\
1998 & $77.4 \%$ & $76.8 \%$ & $65.6 \%$ & $79.4 \%$ \\
1999 & $77.2 \%$ & $76.9 \%$ & $64.7 \%$ & $77.1 \%$ \\
2000 & $78.9 \%$ & $77.0 \%$ & $67.0 \%$ & $79.6 \%$ \\
\hline
\end{tabular}

Note: Data are from S\&P's ExecuComp database, and include only firms where at least one of the top five executives received options during the year. S\&P 500 exclude financial services (SIC codes 6000-6999) and utilities (49004999). Smaller firms are those in S\&P's MidCap 400 and SmallCap 600 . New economy firms are defined as companies with primary SIC codes 3570,3571 , $3572,3576,3577,3661,3674,5045,5961,7370,7371,7372$, and 7373 .

The increasing prevalence of broad-based option grants offers clear evidence that option plans are not exclusively motivated by optimal contracting concerns. But neither are such plans an obvious implication of the managerial power view. Given that the escalation in executive pay is largely driven by options, it is worth exploring explanations that are consistent with the increased use of options throughout the company. I offer as an alternative view to both optimal contracting and managerial power a hypothesis based on two assumptions. First, risk-averse and undiversified employees (rationally) perceive that stock option compensation is highly risky and discount the value of options appropriately. Second, companies routinely but erroneously perceive options as relatively low-cost ways to convey compensation. In the remainder of this Part, I will justify these assumptions and demonstrate that this "perceived-cost" view helps explain the escalation in both CEO pay and broad-based option plans and is also consistent with the evidence BFW offer in support of their managerial power hypothesis.

\section{A. Assumption 1: Undiversified Employees Perceive Options as Having Low Values}

Compensation consultants and academic researchers routinely use standard option pricing models (such as Black-Scholes) to ap- 
proximate the value of stock options. ${ }^{27}$ However, while these models are appropriate for valuing options traded on exchanges, they are not appropriate for valuing options held by undiversified, risk-averse employees who can not freely sell the options or hedge their risk. In two recent papers, Brian Hall and I show that undiversified employees value options at only a fraction of their Black-Scholes value. ${ }^{23}$ In support of this result, we offer evidence that executives participating in exchanges of cash for stock options typically demand large "risk premiums" and that executives routinely complain that Black-Scholes values are not adequately adjusted for risk and non-transferability. In addition, we show how incorporating risk into the analysis has implications for a wide range of compensation practices, including exercise prices, repricing behavior, vesting provisions, and early exercise policies and practices.

\section{B. Assumption 2: Companies Perceive Options as Inexpensive Ways to Convey Compensation}

The economic (or "opportunity") cost of an option is appropriately measured as the amount an outside investor would pay for the option. The outside investor is generally free to trade or sell the option and also can take actions (such as short-selling the underlying stock) to hedge away the risk of the option. Ignoring complications related to potential forfeiture and early exercise, standard methodologies such as Black-Scholes provide an estimate of what an outside investor would pay and are, therefore, appropriate for measuring the company's cost of granting options.

From the perspective of many boards and practitioners, however, the cost of granting options is perceived to be far below their true economic cost. Options are perceived as inexpensive because they can be granted without any cash outlay and without incurring an accounting charge. ${ }^{29}$ Moreover, under U.S. accounting and tax rules, when op-

27 Fischer Black and Myron Scholes, The Pricing of Options and Corporate Liabilities, $81 \mathrm{~J}$ Polit Econ 637 (1973); Robert C. Merton, Theory of Rational Option Pricing, 4 Bell J Econ \& Mgmt Sci 141 (1973) (using Black-Scholes and other theories to derive formulas for pricing put and call options).

28 See Brian J. Hall and Kevin J. Murphy, Stock Options for Undiversified Executives, $33 \mathrm{~J}$ Acct Econ 3, 13-15 (Feb 2002); Brian J. Hall and Kevin J. Murphy, Optimal Exercise Prices for Executive Stock Options, 90 Am Econ Rev 209,211 (2000).

29 Although companies may take an immediate charge for options granted under Statement 123 of the Financial Accounting Standards Board, most companies choose to account for options using Accounting Principles Board Opinion No. 25. Under APB 25, the compensation expense associated with an employee stock option grant equals the "spread" between the fair market value and the exercise price at the date that both the number of shares and the exercise price are determinable or "fixed." Typical options that vest with the passage of time, and that have an exercise price equal to the fair market value on the date of grant, qualify for "fixed accounting" and generate zero compensation expense (since the number of shares and exercise 
tions are exercised, accounting income is unchanged, but taxable income is reduced. The primary cost of options as perceived by many boards is the "dilution cost" which can be mitigated through stock repurchase programs. ${ }^{30}$

BFW consider but largely dismiss accounting explanations for option practices because the value of option grants is disclosed in footnotes to the annual report even though not included in reported income. They claim that, if stock markets are reasonably efficient, imposing an accounting charge on stock options would reduce reported earnings but would not affect stock prices (because the information is already available through footnote disclosure) and, therefore, should not affect option-granting practices. I fully accept that markets are reasonably efficient and also agree that imposing an accounting charge would not directly affect company stock prices. However, based on countless discussions (often heated arguments) with compensation consultants, practitioners, and executives, I am convinced that managers are fixated on the accounting consequences of alternative compensation practices and that this fixation reflects more than the effect of accounting rules on stock prices.

There is substantial evidence that managers respond to accounting concerns in ways that seem irrational to financial economists. For example, when Statement 106 of the Financial Accounting Standards Board was passed, imposing an accounting charge for post-retirement health-care liabilities, managers predicted that stock prices would fall with reported income. Stock prices did not fall (because markets are efficient and the economic liability was already incorporated in stock prices), but companies nonetheless made dramatic cutbacks in the medical benefits for retirees. ${ }^{31} \mathrm{I}$ believe that companies would respond even more dramatically to changes in the accounting treatment of stock options.

price is fixed as of the grant date, and the spread is zero on the grant date).

30 See Kathleen M. Kahle, When a Buyback Isn't a Buyback: Open Market Repurchases and Employee Options, 63 J Fin Econ (forthcoming 2002) (noting that firms prefer repurchasing options since the per-share value of the firm remains unchanged).

31 See, for example, Thomas Watterson, Accounting Changes Bad for Retirees, Boston Globe 51 (Jan 18, 1993) (" $[D]$ amage control will come at the expense of current and retired employees"); Ellen E. Schultz, This Won't Hurt: Companies Transform Retiree-Medical Plans Into Source of Profits, Wall St J A1 (Oct 25, 2000) (discussing the effect of Financial Accounting Standard 106 on retiree benefits). 
TABLE 4

COMPANIES REPRICING STOCK OPTIONS, 1992-2000

\begin{tabular}{|c|c|c|c|c|c|c|c|c|}
\hline \multirow[b]{2}{*}{$\begin{array}{l}\text { Fiscal } \\
\text { Year }\end{array}$} & \multicolumn{4}{|c|}{$\begin{array}{l}\text { PANELA. } \\
\text { All Firms }\end{array}$} & \multicolumn{4}{|c|}{$\begin{array}{l}\text { PANEL B. } \\
\text { Companies' } 50 \text { Percent Price Drops } \\
\text { over Prior } 24 \text { Months }\end{array}$} \\
\hline & 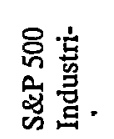 & 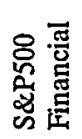 & 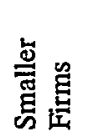 & 害 & 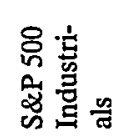 & 总蹗 & 鸪 & 总 \\
\hline 1992 & $0.9 \%$ & $0.0 \%$ & $0.4 \%$ & $9.2 \%$ & $8.3 \%$ & $0.0 \%$ & $0.0 \%$ & $29.4 \%$ \\
\hline 1993 & $0.4 \%$ & $0.0 \%$ & $1.8 \%$ & $7.2 \%$ & $0.0 \%$ & $0.0 \%$ & $13.6 \%$ & $17.9 \%$ \\
\hline 1994 & $0.8 \%$ & $0.0 \%$ & $2.4 \%$ & $2.3 \%$ & $3.6 \%$ & $0.0 \%$ & $13.6 \%$ & $10.0 \%$ \\
\hline 1995 & $0.4 \%$ & $0.0 \%$ & $2.9 \%$ & $7.6 \%$ & $0.0 \%$ & $0.0 \%$ & $20.6 \%$ & $17.9 \%$ \\
\hline 1996 & $1.1 \%$ & $1.6 \%$ & $2.2 \%$ & $10.6 \%$ & $18.2 \%$ & $0.0 \%$ & $10.4 \%$ & $23.7 \%$ \\
\hline 1997 & $0.0 \%$ & $0.0 \%$ & $1.6 \%$ & $16.4 \%$ & $0.0 \%$ & $0.0 \%$ & $7.7 \%$ & $35.7 \%$ \\
\hline 1998 & $1.3 \%$ & $2.9 \%$ & $3.3 \%$ & $12.2 \%$ & $7.5 \%$ & $10.0 \%$ & $7.1 \%$ & $23.1 \%$ \\
\hline 1999 & $0.3 \%$ & $1.4 \%$ & $1.2 \%$ & $3.3 \%$ & $0.0 \%$ & $0.0 \%$ & $1.5 \%$ & $6.7 \%$ \\
\hline 2000 & $0.3 \%$ & $0.0 \%$ & $0.5 \%$ & $0.4 \%$ & $1.4 \%$ & $0.0 \%$ & $1.1 \%$ & $0.6 \%$ \\
\hline
\end{tabular}

Note: Data are from S\&P's ExecuComp database. S\&P 500 excludes financial services (SIC codes 6000-6999) and utilities (4900-4999). Smaller firms are those in S\&P's MidCap 400 and SmallCap 600. New economy firms defined as companies with primary SIC codes 3570,3571 , $3572,3576,3577,3661,3674,5045,5961,7370,7371,7372$, and 7373. Panel $B$ is based on a subsample with fiscal-year closing stock prices less than 50 percent of the (split-adjusted) high price over the twenty-four months preceding the fiscal closing.

The recent change in accounting rules for option repricing illustrates the importance of accounting considerations in stock-option practices. ${ }^{32}$ Before December 15, 1998, companies granting new or repriced options with an exercise price equal to the grant-date market price were not subject to an accounting charge. After this date, companies repricing options must use "variable accounting" where accounting charges are realized annually based on stock-price appreciation.

Table 4 explores the incidence of option repricing among different groups of firms from 1992 through 2000. Panel A shows the prevalence of repricing independent of performance, while Panel B shows the prevalence of repricing for companies experiencing price declines of 50 percent or more over the prior twenty-four-month period. Three primary results emerge. First, with only a few exceptions, smaller firms and new economy firms are more likely to reprice un-

32 For detailed analyses of this accounting-rule change, see Mary Ellen Carter and Luann J. Lynch, The Effect of Accounting on Economic Behavior: Evidence from Stock Option Repricing, working paper (2001), available online at <http://www.columbia.edu/ mec75/repricing1abstract.pdf (visited Apr 19, 2002).

33 The results are robust to other definitions of "poor performance." 
derwater options than are S\&P 500 companies. Second, until 1999, small and new economy firms did not appear reluctant to reprice options following stock-price declines. Third, in spite of the market downturn beginning in spring 2000 , repricings virtually disappeared in small and new economy firms following the December 1998 changes in accounting rules. ${ }^{34}$ Given the market downturn for small and new economy firms, we would have expected an escalation of repricing programs in these companies. The virtual disappearance of repricing programs provides strong evidence of the importance of accounting considerations in compensation decisions.

\section{Implications}

The perceived-cost view based on the two assumptions described above yields predictions consistent with a variety of practices cited by $\mathrm{BFW}$, including the absence of indexed options, uniform exercise prices, repricing, reload options, and international differences in CEO pay. In addition, the perceived-cost view helps explain the escalation in option-based compensation for both top-level and lower-level executives.

\section{Market-indexed options.}

BFW's primary evidence supporting the managerial power hypothesis is that options are not adjusted for market movements. The theoretical motivation for awarding indexed options is typically based on relative performance evaluation (RPE) for risk-averse employees: to the extent that company stock returns are affected by common market-wide shocks, paying based on relative performance can reduce the "noise" in the performance measure without affecting incentives." Therefore, the company switching from absolute to relative performance could reduce compensation (leaving the executive with the same incentives and at the same expected utility but increasing profits) or could increase incentives (keeping both company costs and expected utility constant).

However, the traditional argument for RPE does not translate into option-type instruments, where payouts are realized only if per-

34 In fact, most of the repricings attributed to fiscal year 1999 in Table 4 are from companies with June 1999 fiscal closings that repriced prior to December 15, 1998.

35 This theoretical justification for RPE was introduced by Bengt Holmstrom, Moral Hazard in Teams, 13 Bell $\mathbf{J}$ Econ 74 (1982), and explored empirically for CEOs in Rick Antle and Abbie Smith, An Empirical Investigation of the Relative Performance Evaluation of Corporate Executives, 24 J Acct Rsrch 1 (1986) (presenting mixed evidence for RPE but ultimately concluding that it is a factor for some firms); Robert Gibbons and Kevin J. Murphy, Relative Performance Evaluation for Chief Executive Officers, 43 Indust Labor Rel Rev 30-S (1990) (providing stronger evidence for the RPE theory). 
formance beats the market. These instruments introduce additional risk on recipients, who face a much larger probability of realizing a zero payout than they do with conventional options. In fact, given that stock returns are unbounded on the upside, but cannot be less than -100 percent on the downside, the probability that a given stock will earn returns in excess of a value-weighted index is far below 50 percent. In contrast, a typical ten-year, non-indexed option granted at the money will expire in the money more than 80 percent of the time. Therefore, indexed options actually impose more rather than less risk on risk-averse recipients.

The low payout probabilities for indexed options can be mitigated, in part, by offering indexed options with initial exercise prices significantly "in the money." If such options existed, however, they would likely be cited by BFW as evidence of managerial power. In addition, indexed options issued in the money would be subject to an accounting charge (and therefore perceived as costly to granting firms), even following the complex accounting-avoidance techniques offered by BFW. Also, options issued in the money (indexed or otherwise) would not be considered "performance-based" for tax purposes (which would increase the actual cost to granting firms).

\section{Uniform exercise prices.}

Conceptually, stock options could be issued with exercise prices above, below, or equal to the grant-date market value. In practice, however, exercise prices are almost always set equal to the grant-date market price. BFW offer this practice as evidence of the managerial power hypothesis, since lower exercise prices are "value maximizing for managers" and because the grant-date price is the "lowest possible exercise price consistent with other constraints. ${ }^{36}$ However, the practice is more easily explained by understanding the value and the perceived-cost of executive stock options.

From the perspective of the company, the perceived cost of granting in-the-money options is considerably higher than the perceived cost of granting out-of-the-money options. Options with exercise prices below grant-date market prices incur an accounting charge equal to the grant-date "spread" between the market and exercise price. In addition, under Section 162(m) of the Internal Revenue Code, "non-performance-based" compensation in excess of $\$ 1$ million is considered unreasonable and therefore not deductible as a compensation expense. In order for option plans to qualify as performancebased compensation, the options must not be in the money when 
granted. ${ }^{37}$ Similarly, tax-favored Incentive Stock Options (ISOs) must also have exercise prices at or equal to the grant-date market price.

From the perspective of the employee, options issued at or in the money work best. Managers will naturally prefer options with lower exercise prices to options with higher exercise prices. In our earlier work, Brian Hall and I show that a risk-averse, undiversified executive will prefer a small number of options with a low exercise price to a larger number of options with a higher exercise price, where the number of options is varied to maintain a constant economic cost. ${ }^{38}$ In addition, we show that, when options are awarded as "add-ons" to existing compensation plans without meaningful reductions in other forms of compensation, incentives are maximized by setting exercise prices at or near grant-date market prices. When options are not an add-on to existing compensation, we show that incentives are maximized by granting options with exercise prices set below grant-date market prices. Therefore, because executives are risk-averse and undiversified, it is almost always optimal to set exercise prices at or below grant-date market prices and almost never optimal to set exercise prices above grant-date market prices.

The result that options should be issued at or in the money may seem counterintuitive, since stock prices are expected to increase over time and option-holders will benefit from routine appreciation. However, human resource practitioners have long advocated that incentive plans are most effective when at least partial payouts are likely. Setting high exercise prices reduces the payout probabilities, which in turn reduces the incentive effectiveness for options held by risk-averse and undiversified managers.

In summary, options are most valuable (from the employee's perspective) when issued at or in the money, and options are least costly (from the employer's erroneous perspective) when issued at or out of the money. The natural implication is that options will be issued at the money. BFW reach a similar conclusion but suggest more sinister underlying motives.

\section{Resetting exercise prices.}

Options that fall out of the money are perceived to be nearly worthless to undiversified recipients (because risk-averse individuals discount payouts that occur with small probabilities). Boards concerned about retaining incumbent employees, while also (erroneously)

37 See David M. Schizer, Executives and Hedging: The Fragile Legal Foundation of Incentive Compatibility, 100 Colum L Rev 440, 468 n 101 (2002) (discussing the tax consequences of in-themoney option grants).

38 Hall and Murphy, $33 \mathrm{~J}$ Acct Econ at 15-17, 23-26 (cited in note 28). 
perceiving the costs of making new grants to be low, will naturally tend to reprice options when prices fall. As discussed above, the perceived cost of repricing options increased after the December 1998 accounting change, thus explaining the virtual disappearance of repricing activity after this date.

BFW emphasize two "puzzles" related to repricing practices: (1) options are only repriced after market downturns and are not symmetrically repriced after market upturns, and (2) repricing policies that are expected by executives distort managerial incentives ex ante. The first puzzle can be explained by risk-averse employees who asymmetrically view downside and upside risk. The second puzzle is best understood by noting that most options are awarded to lowerlevel managers and employees who are not making decisions that directly affect stock prices. In fact, during the 1990s, many companies repriced options for all employees except the top-five executives.

\section{Freedom to unwind incentives.}

BFW assert that "firms take surprisingly few steps to prevent executives from unwinding the incentives provided by the grant of options and restricted stock," and offer this evidence in support of the managerial power hypothesis. ${ }^{40}$ The assertion is likely overstated. Top executives are often subject to formal or informal ownership guidelines that restrict their ability to hedge the risk in personal stock holdings (or to use sales of personal holdings to unwind the risk in new option grants). In addition, although it is possible to unwind the risk of unrestricted stock holdings, it is much more difficult to unwind the risk of options and restricted stock. First, recipients cannot directly hedge the risk of options and restricted stock since they are precluded from trading these securities or pledging these securities as collateral and are also precluded from short-selling company stock. In addition, as noted by David M. Schizer, there are unfavorable tax consequences to hedging options and restricted stock."

39 The practice of repricing options below the top five likely reflects punitive SEC disclosure requirements adopted in 1993. In particular, companies repricing options for "proxy-named" executives are required to provide a justification for the repricing and a detailed table showing all repricings over the prior ten-year period. Companies can circumvent these disclosure requirements by repricing options for lower-level executives (without triggering disclosure) while issuing new options for top-five executives (without canceling existing options).

40 Bebchuk, Fried, and Walker, $69 \mathrm{U}$ Chi L Rev at 824 (cited in note 4).

41 See Schizer, 100 Colum L Rev at 474-94 (cited in note 39) (showing that if the option or restricted stock appreciates after the executive has hedged, the executive will realize ordinary income on the appreciation and an offsetting capital loss on the derivative, but explaining that hedging is made unappealing by the "mismatch" which results because capital losses cannot be used to avoid tax on ordinary income). 
In any case, if options are granted (especially below the topmanagement group) not to create optimal incentives but rather because options are perceived to be a low-cost way to convey compensation, and if recipients rationally understand the risk (due to nondiversification) of options, then it is not surprising that companies allow executives to at least partially unwind the risk through personal portfolio decisions. Therefore, allowing partial "risk unwinding" is consistent with the perceived-cost view of executive compensation.

\section{Reload options.}

When an employee exercises an option with a reload provision, he receives additional options with an exercise price set to the market price when the original options were exercised (and the additional options were granted). The number of new options granted equals the shares sold to pay the exercise price plus (often, but not always) shares sold to pay the personal income tax owed on the gain.

Reload provisions are attractive to risk-averse option holders who want to "lock in" a gain from options without forfeiting the "future option value" by exercising early. The economic cost to companies granting options with reload provisions is high (and the fact that the company is subsidizing the tax payments largely ignored), but the perceived cost of adding the provision is low, because the company incurs neither cash drain nor accounting charges in adding reload provisions to option plans. Therefore, reload provision are consistent with the perceived-cost view of executive compensation.

\section{International differences in CEO pay.}

CEOs in the U.S. receive substantially higher pay levels than CEOs in other countries, even after controlling for size, industry, and other environmental and managerial characteristics. The difference in U.S. pay practices is largely (but not entirely) explained by stock option compensation, which is much more intensively utilized in the U.S.

Although one cannot make sweeping generalizations regarding the accounting and tax treatment of option grants outside of the U.S., the European data, coupled with the perceived-cost view, suggest that options are perceived to be less expensive in the U.S. than elsewhere. In particular, companies in the U.S. incur no accounting charge when granting options but receive a tax deduction when the options are exercised. In Europe, however, the accounting and tax treatment tends

42 See Martin J. Conyon and Kevin J. Murphy, Stock-Based Compensation, in J. McCahery and L. Renneboog, eds, Convergence and Diversity in Corporate Governance Regimes and Capital Markets (forthcoming Oxford 2002). 
to be symmetric: if options are invisible in accounting statements, they are likely invisible for tax purposes as well. Similarly, if companies deduct as compensation expense amounts paid in stock-based compensation, they are likely required to take a charge against accounting earnings as well. These tax and accounting differences can help explain why U.S. boards are more generous with their option grants than are boards in other countries. This evidence, while not fully explaining international differences in CEO pay, is largely consistent with the perceived-cost view of executive compensation.

\section{Solutions}

Under the perceived-cost view, compensation decisions are based on the perceived cost rather than the (much higher) economic cost of executive and employee stock options. The perceived-cost view helps explain many of the details of options plans (exercise prices, vesting schedules, etc.) analyzed by BFW. More importantly, the perceivedcost view explains the proliferation of broad-based option programs, which are difficult to justify on an economic basis. Simply put, when decisions are based on perceived rather than economic costs, too many options are granted to too many people.

The economic cost of an option is the "opportunity cost," the amount the company could raise if it sold the option to an outside investor rather than giving it to the executive. When an executive receives a share of restricted stock, the company understands that the cost of that grant is the market price of the share (perhaps with a discount for potential forfeiture). But because there is no market for company options issued with characteristics similar to those granted to executives, the opportunity cost is not obvious. The Black-Scholes formula, with appropriate adjustments for potential forfeiture and early exercise, offers a theoretical estimate of the opportunity cost of executive stock options. This estimate will naturally be above both the perceived cost of options and the value of options from the perspective of risk-averse undiversified recipients.

The fact that compensation decisions are based on perceived rather than economic costs represents a market failure of sorts, similar to managers who ignore the cost of equity capital when making decisions regarding investments, inventories, and working capital. The solution to this market failure may include remedial education on opportunity costs for executives, accountants, analysts, and humanresource practitioners. A more direct, but controversial, solution involves imposing an accounting charge for stock options. I believe that an accounting charge would halt the proliferation of broad-based 
plans and would cause companies to limit stock option grants to toplevel executives whose actions directly affect company stock prices.

\section{CONCLUSION}

Bebchuk, Fried, and Walker present a compelling case that optimal contracting concerns do not explain the level and structure of executive compensation in U.S. corporations. They offer as an alternative hypothesis that CEO-influenced boards design pay plans to transfer rents to top executives in ways that mitigate public outrage. Evidence offered in support of the managerial power view is almost exclusively related to features of stock option plans, including why exercise prices are set at grant-date market prices and are not indexed to general market movements, why options are "repriced" following market downturns, why options often contain "reload" provisions, why firms allow executives to exercise early and diversify (or otherwise hedge the risk of their option and stock holdings), and why options are more prevalent in the U.S. than abroad. ${ }^{43}$

I offer evidence inconsistent with the managerial power hypothesis and provide an alternative hypothesis based on two assumptions: (1) because of accounting and cash-flow considerations, companies (erroneously) perceive the cost of granting options to be far below their economic cost, and (2) risk-averse undiversified optionrecipients (rationally) perceive the value of options to be below the company's economic cost of granting options. I show that this "perceived-cost" view is consistent with the evidence presented by BFW, as well as with other practices such as broad-based option programs that are difficult to justify from an optimal contracting standpoint.

The managerial power and perceived-cost views of executive compensation offer similar predictions about pay patterns and practices but differ significantly in their policy implications and prescriptions. In particular, mitigating managerial power problems suggests

43 In addition to the option-related evidence, BFW also discuss "gratuitous acquisitionrelated goodbye payments" as evidence supporting the managerial power hypothesis. Since, unlike the other evidence presented, these payments are not directly related to the details of stock-option grants, I do not offer a perceived-cost explanation for these payments. However, some remarks are in order. BFW define as "gratuitous" any payments that are not explicitly mandated by existing change-in-control agreements. However, virtually all the evidence offered by BFW relates to terms of explicit ex ante change-in-control agreements; they offer scant evidence on the prevalence or magnitude of ex post payments. Moreover, such payments (to the extent they exist) are not obviously gratuitous or inconsistent with arm's length bargaining. For example, boards might pay special bonuses for extraordinary (and unanticipated) efforts in connection with a merger, or the acquirer might pay retention bonuses to enlist the outgoing executives' help during the critical transition period. Overall, while I am sympathetic to the view that incumbent managers can resist takeover attempts (and am even comfortable calling this "managerial power"), I do not see the distinction between ex ante and ex post as particularly relevant to the analysis (except in highlighting that ex ante contracts are often incomplete). 
revising corporate governance to require truly independent boards, without any real evidence that such changes would lead to improved corporate performance or more rational compensation decisions. In contrast, mitigating perceived-cost problems suggests educating managers and boards on the true economic costs of stock options, imposing accounting charges for option grants, and eliminating the asymmetry between the accounting and tax treatment of executive and employee stock options. 


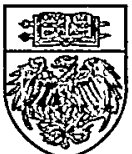

